\title{
Irineu Evangelista de Souza na Guerra Grande: o intermediário dos contratos secretos entre o Brasil e o Uruguai em 1850*
}

\author{
Irineu Evangelista de Souza in the "Guerra Grande": the \\ intermediary of secrets contracts between Brazil and Uruguay in 1850
}

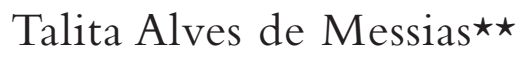

Resumo: O trabalho tem como objetivo explorar o papel de intermediador desempenhado por Irineu Evangelista de Souza, futuro barão e depois visconde de Mauá, nos contratos de empréstimos financeiros realizados pelo Império do Brasil ao governo do Uruguai em 1850, no início da chamada Diplomacia do Patacão. A análise é baseada no cruzamento de dados entre as fontes documentais relacionadas à Diplomacia do Patacão em 1850 e os dados e análises presentes na historiografia sobre o assunto. $\mathrm{O}$ estudo indica que Irineu foi convidado para atuar nessa política apenas como intermediador, de modo a tornar mais plausível o cenário que os agentes do Império visavam criar, mas que sua participação na ação secreta lhe permitiu combinar o acesso a informações privilegiadas da geopolítica regional com oportunidades de negócios, nas quais ele decidiu investir.

Palavras-chave: Diplomacia do Patacão. Irineu Evangelista de Souza. Mauá. Guerra Grande. Empréstimos.

Abstract: The work aims to explore the role of intermediary played by Irineu Evangelista de Souza, future baron, and later viscount of Mauá, in the financial loan contracts made by the Empire of Brazil to the government of Uruguay in 1850, at the beginning of the "Patacão Diplomacy". The analysis is based on the crossing of data between the documentary sources related to the "Patacão Diplomacy" in 1850 and the data and analyzes present in the historiography on the subject. The study indicates that Irineu was invited to act in this policy only as an intermediary,

\footnotetext{
* Submissão: 03/03/2021 | Aprovação: 04/08/2021 | DOI: 10.29182/hehe.v24i3.807

O presente trabalho foi realizado com apoio da Coordenação de Aperfeiçoamento de Pessoal de Nível Superior - Brasil (CAPES) - Código de Financiamento 001. Uma primeira versão deste texto foi apresentada no X Encontro de Pós-graduação em História Econômica \& $8^{a}$ Conferência Internacional de História Econômica, em novembro de 2020.

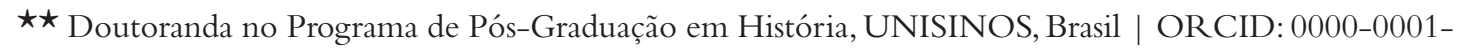
8173-8012 | E-mail: talita-alves@hotmail.com
} 
to make the scenario that the agents of the Empire intended to create more plausible, but his participation in the secret action allowed him to combine access to privileged information from regional geopolitics with business opportunities, in which he decided to invest.

Keywords: Patacão Diplomacy. Irineu Evangelista de Souza. Mauá. Guerra Grande. Loans.

JEL: N46. 


\section{Introdução}

Em 1850, o Império do Brasil se tornou credor internacional da República Oriental do Uruguai por meio de uma convenção secreta, iniciando assim sua intervenção na guerra que venceria dois anos depois. Essa política ficou conhecida como Diplomacia do Patacão, termo cunhado provavelmente pelo historiador argentino José Ramón Cárcano, claramente em analogia à “Diplomacia do Dólar". 1 A Diplomacia do Patacão contribuiu para que o Brasil se consolidasse, com o fim da Guerra Grande, em uma posição dominante no jogo geopolítico regional ao longo das décadas de 1850 e 1860 . Sua presença na região, enquanto "um outro Império", apresentava-se com uma "relação complementar, subordinada e contraditória com o polo dominante capitalista das relações internacionais": as potências europeias (Salles, 1990, p. 49). Nesse sentido é que Irineu Evangelista de Souza, ${ }^{2}$ futuro barão e depois visconde de Mauá, enquanto intermediário e financista, aparece nessa política brasileira como uma "força paralela e soberana" ao Império do Brasil, segundo as palavras de Lídia Besouchet (1977, p. 20). O país que já nascera devedor internacional em seu contrato de independência, tornar-se-ia credor internacional na região platina.

$\mathrm{Na}$ historiografia que tratou especificamente desse início da Diplomacia do Patacão, que pode ser dividida grosso modo em biografias de Mauá e estudos de história diplomática, a atuação de Irineu é imprecisa. Nas biografias, como de Faria (1933), Caldeira (2004), Besouchet (1977, 1978) e Marchant (1965), é comum a exaltação ao seu patriotismo e a confusão com relação aos recursos utilizados nos empréstimos, tratados como se fossem todos do próprio Irineu. Nos trabalhos mais relacionados à história diplomática, como Soares (1957), Bandeira (2012), Barrera (2015), Almeida (2005) e Souza (2013), embora essa questão sobre recursos públicos ou privados seja mais ponderada, não houve um estudo mais aprofundado sobre o assunto para esclarecer essa

\footnotetext{
${ }^{1}$ Cárcano faz a analogia no texto Del sitio de Buenos Aires al campo de Cepeda: 1852-1859, publicado em 1921 (p. 488). O autor chegou a comentar em nota de rodapé que o político francês Pierre Baudin chamou de Diplomacia dos Negócios o que os norte-americanos chamaram de Diplomacia do Dólar. A Diplomacia do Dólar foi uma política estadunidense definida pelo Presidente William Howard Taft (1909-1913) da seguinte forma: "A diplomacia da atual administração busca estar de acordo com as idéias (sic) modernas sobre intercâmbio comercial. Esta política tem sido caracterizada como a substituição de balas por dólares. Ela apela igualmente aos sentimentos humanitários idealísticos, aos ditames da política e da estratégia sensatas, e aos objetivos comerciais legítimos" (Taft, 2012 apud Carr, 2001, p. 164).

${ }^{2}$ Irineu recebeu a comenda da Imperial Ordem da Rosa em 1851, o título de barão de Mauá em 1854 e de visconde em 1874. Optamos por chamá-lo de Irineu neste trabalho para reforçar que estamos tratando do período anterior a essas honrarias, no início da construção desse poder simbólico que Irineu acumularia ao longo do período imperial.
} 
questão. A imprecisão dessas análises é compreensível, porque realmente Irineu chegou a empregar recursos privados no contexto das guerras platinas daquele período, tornando-se inclusive importante banqueiro na região a partir de meados da década de 1850. Logo, o objetivo deste trabalho é analisar o papel de intermediador de Irineu Evangelista de Souza nos primeiros contratos realizados na Diplomacia do Patacão, diferenciando-o de sua ação de financista da região da Bacia Platina.

O trabalho iniciará logo após essa introdução contextualizando a ação das potências europeias nessa região, de modo a compreender os precedentes das políticas creditícias em que o Brasil se envolveria com seu intermediador. A Guerra Grande, que iniciou em 1838, teve a interferência dos governos da França e da Inglaterra, que estendiam para a região suas políticas ofensivas em busca de expansão comercial.Além das ações bélicas e bloqueios portuários, empréstimos e subsídios também foram oferecidos por esses países de modo a garantir a liberdade de navegação do Rio da Prata e os interesses de seus súditos nessa região. Foi a progressiva retirada dessas potências do conflito que tornaram urgentes a intervenção brasileira, tanto do ponto de vista do governo sitiado em Montevidéu quanto do próprio Império do Brasil.

No tópico seguinte, será analisada a primeira parte das negociações secretas do Brasil, que visava ao fornecimento de armas e outros materiais de guerra ao governo de Montevidéu. Através de sua empresa de fundição e estaleiro, Irineu já iniciava sua participação na estratégia geopolítica brasileira. Já no último tópico são analisados os contratos acerca dos subsídios financeiros que marcaram o início da Diplomacia do Patacão, percebendo como se deram as participações de Irineu nessa política. Este trabalho faz parte de uma pesquisa de tese de doutorado e suas considerações preliminares são resultantes do cruzamento entre a análise das fontes documentais relacionadas à Diplomacia do Patacão em seu primeiro ano (1850) e os dados e análises presentes na historiografia sobre o assunto.

\section{A geopolítica da Bacia do Rio da Prata: as potências europeias e os antecedentes da política de subsídios}

A Guerra Grande iniciou-se com a disputa pelo controle do governo da Banda Oriental, atual Uruguai. De um lado estava Manuel Oribe, como representante do partido Blanco, que renunciou à presidência do país após perder a Batalha do Palmar (junho de 1838); do outro lado estava Fructuoso 
Rivera, do partido Colorado, que após a renúncia de seu opositor destituiu o presidente do Senado da chefia do Poder Executivo, dissolveu as Câmaras e assumiu o mando do Estado. De uma guerra civil, o conflito ganhou uma segunda dimensão quando o ex-presidente Oribe se refugiou em Buenos Aires e lá foi reconhecido pelo governante Juan Manuel de Rosas como se ainda estivesse no poder, gerando a declaração de guerra uruguaia a este último em fevereiro de 1839 e assegurando o caráter internacional ao conflito. Essa foi uma guerra de circunstâncias bastante complexas, tanto devido à multiplicidade de atores e à inconstância das alianças formadas quanto pela diversidade de motivos, razões e interesses que estavam envolvidos nessas disputas.

Em linhas gerais, a Guerra Grande reflete a indefinição em que ainda se encontravam as unidades territoriais que comporiam os Estados da região platina, especialmente os que hoje conhecemos por Argentina e Uruguai, ${ }^{3}$ mas também com relação ao Brasil e ao Paraguai. Depois de anos de guerra ao fim do período colonial pela independência dos países platinos, o processo de organização desses territórios ainda ocasionou outros tipos de conflitos, centralizados na disputa dos grupos regionais pelas terras férteis e gado, assim como pelo controle do Estado e das rendas provenientes de impostos e tarifas, sobretudo aduaneiros. No caso do Uruguai, esses conflitos desencadearam essa guerra internacional, que acabou por dividir seu território em dois governos: o da Defensa, do partido Colorado, que estava sitiado em Montevidéu desde 1843, e o governo do Cerrito, do partido Blanco, que abarcava a maior parte do território do país e era liderado por Manuel Oribe e apoiado pelo argentino Rosas. ${ }^{4}$

Diversas questões estavam em jogo nesse contexto conforme a guerra superava o território uruguaio e envolvia a Confederação Argentina, Brasil, Inglaterra e França. Mas havia um ponto que unia a preocupação de todas as unidades territoriais envolvidas na Guerra Grande: era o acesso aos rios da Bacia do Rio da Prata. Essa é a segunda maior bacia hidrográfica da América

\footnotetext{
${ }^{3}$ Denominada de Províncias Unidas da América do Sul, Províncias Unidas do Rio da Prata, República Argentina e ainda Confederação Argentina, esse Estado em construção desde 1816 que hoje conhecemos como Argentina só teve sua unificação definitiva em 1861. Já o Uruguai, mais conhecido à essa época que tratamos no artigo como Banda Oriental, teve sua independência reconhecida em 1828 pela Convenção Preliminar de Paz firmada entre o Império do Brasil e as Províncias Unidas do Rio da Prata, mediada pelos ingleses. Por meio desse pacto os dois países comprometiam-se pela independência do novo Estado. ${ }^{4}$ Com a aliança de Rosas e liderando o exército da Confederação, Oribe conseguiu avançar com suas tropas até Montevidéu, mantendo a cidade sitiada em 16 de fevereiro de 1843. Esse cerco que parecia questão de tempo para derrotar a capital, durou oito anos.
} 
do Sul, que integra naturalmente o interior desse território ao oceano Atlântico por seus rios caudalosos e em grande parte navegáveis. Em tempos em que as viagens por terra ainda eram bastante lentas e dificeis, o domínio dos rios era fundamental para dar acesso ao interior do continente sul-americano, como a província brasileira de Mato Grosso. Por isso essa região que já havia sido tão disputada ao longo do período colonial entre Portugal e Espanha, passaria a vivenciar conflitos pela liberdade de navegação em que o couro e a erva-mate substituíam a prata do período colonial como principais produtos de exportação (Puiggrós, 2006, p. 39).

Nesse sentido, o epicentro da Guerra Grande era Montevidéu, mas o principal personagem estava do outro lado do Prata: era Juan Manuel de Rosas, em Buenos Aires. Ao visar ao domínio sobre a navegação dos rios Paraná e Uruguai, o plano de Rosas era inaceitável aos demais países platinos, às províncias argentinas ribeirinhas a esses rios, ${ }^{5}$ e mesmo à França e à Inglaterra. Para consolidar esse projeto, seria necessário a Rosas o controle sobre Montevidéu e o Paraguai, por meio da incorporação deste último à Confederação Argentina e o que em termos territoriais se assemelhava ao antigo Vice-Reino do Rio da $\operatorname{Prata}^{6}$ (Fradkin; Gelman, 2015, p. 344). Se "estar perto de um porto era estar perto do mundo", como afirmou Hobsbawm (2019, p. 31), estar em Buenos Aires e/ou Montevidéu era estar em pontos estratégicos da América do Sul e inserido em disputas locais e globais pelas rendas públicas e oportunidades de comércio. Por isso era fundamental tanto ao Brasil quanto às potências europeias que Montevidéu resistisse.

Para o Brasil, além do acesso a Mato Grosso, tanto o envolvimento pessoal, econômico e político de seus súditos sul-rio-grandenses com os chamados caudilhos platinos quanto as propriedades que aqueles possuíam no Uruguai vinham sendo constantes motivos de preocupação, mesmo passados alguns anos desde o fim da Guerra dos Farrapos (1835-1845) e a reintegração de sua província meridional ao território brasileiro. $\mathrm{Na}$ fluidez das

\footnotetext{
${ }^{5}$ As províncias ribeirinhas que foram se opondo a Rosas questionavam o monopólio do porto exercido por Buenos Aires, sua apropriação excludente das rendas do comércio e seu bloqueio dos rios da Bacia. Com o tempo, foi nessas províncias, sobretudo Corrientes e Entre Rios, que foram encontrados aliados para lutarem contra Rosas e que acabaram por contribuir para sua queda em 1852. "O problema [...] se resumia [...] na necessidade de autodeterminação das economias locais, expressada, contraditoriamente, pelas reivindicações protecionistas e pelos anseios de abertura do Rio da Prata e seus afluentes à navegação. Ninguém queria pagar peagem a Buenos Aires." (Bandeira, 2012, p. 133).

${ }^{6}$ O Vice-Reino do Rio da Prata foi o último vice-reino criado pelo império espanhol, e seu território abarcava os territórios que atualmente são a Argentina, as Ilhas Malvinas, o Uruguai, o Paraguai, a Bolívia, parte do sul do Brasil, do norte do Chile e do sudeste do Peru.
} 
fronteiras, as rivalidades entre as diversas facções que disputavam poder nos países do Prata cruzavam-se e criavam complexas relações econômicas, políticas, ideológicas e pessoais que interferiam nas dinâmicas desses conflitos (Messias, 2018).

Vários brasileiros eram proprietários de terras e gado nos dois lados da fronteira, mas eram também os chefes militares com que contava o governo imperial para defender seu território. ${ }^{7}$ Além disso, também combinando os planos externo e interno da política imperial, a sustentação do regime escravocrata, a sobrevivência de uma monarquia em meio a repúblicas e mesmo a consolidação do projeto nacional brasileiro ${ }^{8}$ estavam em pauta. Ainda assim, o governo brasileiro passou os primeiros anos da guerra buscando não se envolver diretamente, justamente porque sua própria integridade estava ameaçada com os diversos conflitos regionais por todo o país, assim como a instabilidade política dificultava a formulação de uma estratégia mais efetiva para as relações exteriores na região.

Nesse contexto, os governos da França e Grã-Bretanha, maiores rivais econômicos ao longo do século XVIII, adentravam na região disputando o comércio e a influência econômica e política dos países platinos. Os países europeus despendiam recursos, negociavam e tentavam fazer imposições aos governos beligerantes da região platina, mas nem sempre conseguindo garantir seus interesses. O Concerto da Europa que garantiu os cem anos de paz no velho mundo a partir de 1815, contrastou com os caros e sangrentos conflitos na Bacia do Rio da Prata que atravancavam o comércio na região. As lógicas que guiavam esses países que se construíam no Prata eram síntese de múltiplas influências que tornavam incontroláveis até mesmo os súditos europeus que ali viviam.

A complexidade de compreender a Guerra Grande está em assimilar os conflitos que ocorriam dentro das unidades territoriais participantes e que se espalharam para fora de suas fronteiras ainda tão pouco definidas, encontrando os conflitos dos países vizinhos. Além disso, a guerra inseria-se nos movimentos mundiais de comércio e por busca de influência sobre esses Estados

\footnotetext{
${ }^{7}$ Diversos estudos ajudam a compreender o papel dos súditos sul-rio-grandenses na Guerra Grande por meio do estudo de suas propriedades no Uruguai, das disputas pelos estoques de gado, das relações políticas, econômicas e pessoais com os caudilhos platinos, assim como da discussão acerca da fluidez dessa fronteira meridional. Nesse sentido, destacamos os trabalhos de Menegat (2015), Vargas (2013), Guazzelli (2013) e Flores (2014).

${ }^{8}$ Para Gabriela N. Ferreira (2006, p. 224), a ação do governo imperial em meados do século XIX "buscava eliminar os potenciais perigos à ordem interna que parecia finalmente estabelecida em 1850”, mais até do que a própria ameaça externa que toda a conturbada situação do Prata gerava.
} 
em construção. Por mais que na disputa mundial de comércio a preponderância econômica já fosse inglesa, perante a França, o liberalismo que os ingleses vinham tentando introduzir na região misturava-se a ideias republicanas e discussões sobre democracia, aprendidas com os franceses e estadunidenses $^{9}$ (Cain; Hopkins, 2002). A despeito de possuírem capital, armamento, exércitos e desenvolvidas diplomacias, os europeus não conseguiram pacificar a região sozinhos e encerrar a Guerra Grande.

Em Montevidéu, o cerco imposto por Oribe e Rosas reduziu o comércio a zero e a arrecadação aduaneira em 1843 a 6\% do que havia sido recebido no ano anterior (Cady, 1943, p. 137). A cidade ia parecendo cada vez mais próxima de sucumbir ao poder inimigo. Quase dois anos após o início do cerco, os governos da França e da Inglaterra ainda não haviam conseguido chegar a um acordo com Rosas que lhes permitisse o livre comércio na região e resolveram optar pelo bloqueio ao porto de Buenos Aires como mecanismo de pressão, iniciando-o em 22 de setembro de 1845. A ideia era pressionar Rosas para liberar a navegação e o comércio nos portos platinos afetados pela guerra, além de garantir o atendimento a algumas reclamações de seus súditos na região. Mas com esse bloqueio, acabavam garantindo também que Montevidéu não sucumbisse ao cerco e que Rosas não terminasse controlando as duas margens do Prata.

O bloqueio ao porto de Buenos Aires direcionava o comércio da região para Montevidéu, fazendo com que a renda aduaneira desse porto uruguaio multiplicasse por mais de trinta, passando de 86.000 pesos em 1844 para mais de 2.900 .000 pesos 1847 (Barrera, 2015, p. 104). ${ }^{10}$ Essas rendas eram um dos mais importantes ativos da Defensa e já vinham sendo alienadas para a aquisição de empréstimos privados. Segundo a análise de Barrera (2015), o arrendamento das rendas aduaneiras surgiu nessa conjuntura tanto pelo crescimento acentuado dos gastos de guerra quanto pela perda do controle fiscal do território por parte de Montevidéu. Assim, formaram-se sociedades que emprestavam capital ao governo tendo por garantia o controle sobre a totalidade ou parte das rendas da aduana principal, o que o governo fazia a partir de leis que vinculavam as sociedades a um período específico, geralmente anuais

\footnotetext{
${ }^{9}$ Por isso ganharam tanta notoriedade as análises que afirmam que o imperialismo britânico na região era mais uma expansão de influência do que de dominação, uma espécie de "império informal", como bem definiram Cain e Hopkins (2002).

${ }^{10}$ Outro dado apresentado sobre o efeito desse bloqueio: "Las entadas aduaneras se elevaron de 12.000 pesos fuertes por mes a 30.000 en septiembre de 1845, alcanzando a 75.000 en enero de 1846" (Durand, 1853 apud Cady, 1943, p. 170).
} 
(Barrera, 2015). Por ser um dos principais portos da Bacia, receber a garantia de controle das rendas da aduana poderia ser na época uma boa oportunidade de negócio aos prestadores.

Além disso, o apoio europeu a Montevidéu parecia oferecer mais algumas garantias aos negócios da cidade. Empréstimos, subsídios e adiantamentos foram realizados ao governo da Defensa tanto pela Inglaterra entre 1846 quanto pela França a partir de 1848, como veremos a seguir. Enquanto houvesse expectativa sobre esses suportes europeus ao governo de Montevidéu, havia expectativa de empréstimos privados. Empréstimos a Estados em tese possuem maiores garantias porque eles possuem poder de coerção e diversas formas de realizar o pagamento, seja entregando o controle de um setor gerador de receitas para o prestador, como a aduana; seja criando impostos e/ou diminuindo gastos. Mas em um Estado em construção, não consolidado, na periferia do sistema capitalista, tão dependente de auxílio externo e com uma disputa política de sua classe dominante de tão longa duração, emprestar capital acabava sendo uma aposta sobre quem venceria a guerra em um momento em que esse resultado não era claro.

Por isso, em 1848, quando a França ofereceu a Montevidéu o pagamento de subsídios mensais visando à proteção dos franceses estabelecidos naquela cidade, essa passou a ser a principal renda daquele governo sitiado. A Convenção de Subsídios foi assinada em 12 de junho de 1848 (Uruguay, 1922). O acordo era então diretamente entre dois Estados, permitindo o prosseguimento da guerra por parte da Defensa e, assim, a manutenção da oposição a Rosas no governo uruguaio. Por essa Convenção a Defensa receberia mensalmente 40 mil pesos a partir de 30 de junho daquele ano "até que o governo francês tomasse resolução a respeito” (Ferrando, 1969, p. 19). Esses subsídios eram a título de empréstimos, que deveriam ser pagos com renda da Aduana a partir de 1852 e os juros não foram definidos previamente. Eles foram pagos com letras do governo francês e utilizados sobretudo para compra de víveres e manutenção do exército. De junho a dezembro de 1848 a Defensa teria recebido 260 mil pesos em letras francesas e em 1849 o governo francês forneceu as mensalidades acordadas na Convenção, totalizando 480 mil pesos (Ferrando, 1969).

Mas a instabilidade que rondava a Europa naquele período foi tornando os países europeus cada vez menos preocupados com essa região. Entre fins de 1849 e início de 1850, os agentes governamentais da Defensa foram percebendo esse movimento de afastamento das potências europeias. A retirada 
delas do conflito, sobretudo se ocorresse em acordo com Rosas, ameaçava a queda da praça de Montevidéu. Assim, a relação entre guerra e crédito na formação dos Estados latino-americanos exprime um contexto bastante distinto do que se verificou na Europa na formação de seus Estados, porque, apesar de terem abastecido a Europa de metais preciosos, já nasceram dependentes do capital que o velho mundo fornecia. Por isso, a estratégia do governo da Defensa se voltou com ainda mais intensidade para o Brasil. As negociações e pedidos de auxílios e alianças foram se acentuando por meio do representante daquele governo na corte do Rio de Janeiro, Andrés Lamas. Este tinha como missão convencer o Brasil de que era de seu interesse manter afastadas de suas fronteiras "as armas e influências argentinas" e que por isso deveria o governo imperial intervir na Guerra contra Oribe e Rosas (Devoto; Devoto, 1971, p. 94).

Além disso, ainda que o governo imperial seguisse tentando manter a neutralidade no Prata em 1849, alguns estancieiros da Província do Rio Grande iniciaram incursões armadas no território uruguaio com vistas a capturar reses e escravos, episódios que ficaram conhecidos como "califórnias". ${ }^{11}$ Lideradas pelo barão de Jacuí, as chamadas califórnias ocorriam com o objetivo de apoderar-se principalmente do gado que seus participantes ou chefes possuíam do outro lado da fronteira, assim como de escravos que fugiam para o Uruguai, onde a escravidão já havia sido abolida. Essas incursões demonstravam a continuidade tanto da disputa secular por terras e gado nessa fronteira quanto o papel fundamental que os caudilhos gaúchos, enquanto também chefes militares do Império, desempenharam nesses conflitos platinos, colocando o poder central brasileiro em uma situação delicada.

As reclamações diplomáticas do governo do Cerrito para o Império devido às "califórnias", unidas às reclamações dos súditos sul-rio-grandenses por suas propriedades no Uruguai, só pressionavam ainda mais o governo brasileiro, ${ }^{12}$ tornando a conjuntura mais favorável às negociações de Andrés Lamas por apoio à Defensa. Em fevereiro de 1850 Lamas teve um encontro com o Ministro dos Negócios Estrangeiros do Império do Brasil, Paulino Soares de Souza. Para o enviado uruguaio, a gravidade da situação estava no fim do subsídio francês que parecia próximo, já que a França negociava o fim da intervenção na região. Por isso, Lamas pediu ao governo imperial um ato deci-

\footnotetext{
${ }^{11}$ Sobre o tema, ver Franco (2006) e Ribeiro (2021).

${ }^{12}$ Sobre as propriedades dos brasileiros ao norte do Uruguai, onde governava Oribe, ver a tese de Menegat (2015).
} 
sivo de apoio a Montevidéu, que fosse indireto, mas real. Entendendo que o Império aguardava o momento certo para agir, garantia que o governo da Defensa guardaria inviolável segredo sobre essas negociações. ${ }^{13}$

Naquele contexto, a necessidade principal da Defensa era de artigos de guerra,já que os subsídios franceses estavam sendo destinados sobretudo para a compra de víveres. Ou seja, para além da sobrevivência da praça de Montevidéu, o que os agentes daquele governo buscavam era uma guinada na história desse conflito que já havia se estendido demais. Com os artigos de guerra e os soldados que se planejava contratar na Europa, seria possível partir para uma batalha que desse fim ao tão prolongado cerco. Se a sobrevivência da praça de Montevidéu dependia dos subsídios franceses, o fim da guerra dependia da força que só seria possibilitada pelo crédito. Com os detentores de capital privado daquela praça seria difícil consegui-lo, já que, agindo pela lógica de multiplicação de seus investimentos, não poderiam ter muitas expectativas de retorno nesse Estado que não se sabia até quando duraria.

Por isso era mais provável que a ajuda viesse de quem tivesse interesses maiores do que apenas da multiplicação de capital. Os países europeus, negociando com Rosas, já não eram alternativas. Era o Brasil que, pela necessidade de garantir o acesso e a integridade de seu próprio território, assim como a manutenção de suas instituições e seu regime monárquico, teria interesse para uma intervenção mais efetiva na Guerra Grande. A maior estabilidade brasileira em 1850 combinada ao agravamento da situação no Prata propiciou a abertura que Lamas necessitava. Assim sendo, foi relevante compreender o processo de expansão inglesa e francesa nessa região no contexto da Guerra Grande, pois a Diplomacia do Patacão exprime uma relação de hierarquia e dependência dentro de uma região "periférica" e dependente, ou seja, evidencia que na disputa geopolítica global, liderada pelas grandes potências, existem disputas regionais, com dinâmicas próprias, que não necessariamente serão resolvidas ou controladas pelos poderes centrais do sistema interestatal. É essa dinâmica regional, da qual a Diplomacia do Patacão faz parte, que pode oferecer novos subsídios para a compreensão da formação dos Estados latino-americanos do ponto de vista geopolítico e econômico.

\footnotetext{
13 Correspondência de Andrés Lamas a Manuel Herrera y Obes, Rio de Janeiro, 21 de março de 1850 (Correspondencia..., 1915).
} 


\section{Fornecimento de armas e materiais de guerra a Montevidéu}

Antes de declarar guerra a Rosas e comprometer-se abertamente com a Guerra Grande, o Brasil criou outras estratégias para intervir no conflito discretamente: a monarquia de origem portuguesa, devedora de bancos ingleses e na periferia do sistema interestatal capitalista, assumiu o papel de credora da Defensa e alterou a balança de poder da Guerra Grande. Mas antes de fornecer capital, forneceu armas. Em 19 de fevereiro de 1850, Andrés Lamas sugeriu ao Ministro dos Negócios Estrangeiros Paulino Soares de Souza ${ }^{14}$ que buscasse um negociante que aceitasse fornecer artigos de guerra para a Defensa recebendo pagamento de letras a prazo contra o governo de Montevidéu. ${ }^{15}$ Lamas argumentava que mantendo aquela praça, o Império poderia preparar-se para a guerra "com economia de sangue e de dinheiro" e com "menos aventuras e sacrificios": "Sin estar preparados para una buena guerra, es imposible obtener una buena paz. Si vis pacen, para bellum". ${ }^{16}$

Em tempos de guerra, os gastos públicos com esse ramo tendem a ser os maiores do Estado, ${ }^{17}$ de modo que o mínimo que o país deve fazer é "estar sempre em postura de guerra", sendo essa "a maneira menos custosa de evitar que a guerra venha de fora" (Petty, 1983, p. 18). Tendo Montevidéu como aliado, manter a defesa daquela cidade era talvez a melhor forma de o Império seguir esses preceitos da economia política. E o momento era bastante favorável. Com a abolição do tráfico de escravos em 1850, que antes chegava a representar um terço do total das importações do país, havia sobra de recursos na praça do Rio de Janeiro, que passava a ser investida em especulações na bolsa de valores, câmbio ou dívida pública (Schulz, 2013). Com as alianças corretas, o Império poderia conseguir canalizar parte desses recursos para a defesa de seus interesses geopolíticos no Prata.

Nesse contexto, o ministro Paulino respondeu a Lamas logo no dia seguinte, 20 de fevereiro, convidando-o para uma conferência naquela tarde.

\footnotetext{
${ }^{14}$ Paulino Soares de Souza, mais tarde visconde do Uruguai, era um dos líderes da Trindade Saquarema do Partido Conservador." [...] a 'trindade saquarema' constituiria o núcleo do grupo que deu forma e expressão à força que, entre os últimos anos do Período Regencial e o renascer liberal dos anos sessenta, não só alterou os rumos da 'Ação' mas sobretudo imprimiu o tom e definiu o conteúdo do Estado imperial” (Mattos, 1987, p. 108).

${ }^{15}$ Andrés Lamas, Memorandum, Rio de Janeiro, 19 de fevereiro de 1850 (Brasil, 1852, anexo D, N. 1).

16 “Sem estar preparados para uma boa guerra, é impossível obter uma boa paz. Se quer paz, prepare-se para a guerra" (Lamas, 1850, fl. 3. tradução nossa).

17 Garavaglia (2010) mostra o quão significativos foram os gastos com esse ramo na construção dos países latino-americanos.
} 
Naquele encontro, o ministro brasileiro já falou que haveria um negociante que poderia proporcionar a maior parte dos artigos de guerra que seu governo necessitava, inclusive encarregando-se de pagar fretes e outros gastos. A partir disso, os ministros buscaram um intermediário ${ }^{18}$ que conversaria com o tal negociante para manter toda a conversação o mais secreta possível. ${ }^{19}$ Quando Lamas escreveu a Herrera em 21 de março contando sobre a reunião com o ministro Paulino em fevereiro, enviou também alguns documentos que ajudam a compreender o andamento daquelas negociações. Essa primeira operação seria para enviar munições e armas para Montevidéu, mas considerou-se que seria suspeito se repentinamente fossem desembarcados esses materiais na cidade.

Para disfarçar a operação, a ideia era simular um contrato oneroso ${ }^{20}$ entre o comerciante escolhido e a legação uruguaia, fingindo que a transação seria paga com letras do Estado Oriental de modo que parecesse verdadeira. ${ }^{21}$ Desconfiado pelos riscos que tal documento representava ao governo e mesmo à sua própria imagem enquanto enviado plenipotenciário, Lamas escreveu a Castro que a negociação era um socorro oferecido à Defensa e por isso tratá-la como um negócio oneroso parecia-lhe arriscado ao futuro do governo ao qual representava. A resposta, que para Lamas pareceu suficiente por documentar o real teor da negociação, foi que "cuanto más onerosa parezca la transación, tanto más verosímil se volverá y al fin de cuentas Udes. vendrán a pagar lo mismo, esto es, cero". ${ }^{22}$ Poucas informações foram encontradas na historiografia acerca dessa remessa de armamento e mesmo no Relatório da Repartição dos Negócios Estrangeiros a informação foi ocultada. Foi Moniz Bandeira (2012), entretanto, que citou o discurso do deputado Manuel de Mello Franco, do Partido Liberal, em sessão de 1851, que acusa o governo

\footnotetext{
${ }^{18}$ A correspondência o nomeia como "señor Castro, consul de la Republica”. Besouchet afirma que seria José Castro o seu nome e seria cônsul do Uruguai no Brasil. Entretanto, é mais provável que esse "señor Castro" seja Manoel Moreira de Castro, como afirmou Souza (1944, p. 265) que em 1850 era cônsul no Rio de Janeiro tanto da República Oriental do Uruguai quanto da República do Paraguai (Brasil, 1851).

19 Correspondência de Andrés Lamas a Manuel Herrera y Obes, Rio de Janeiro, 21 de março de 1850 (Correspondencia..., 1915).

20 “Ofereço empregar de vinte a vinte e cinco contos de réis nos gêneros constantes de relação reduzindo portanto nas que forem menos necessárias a quantidade que possa exceder aquela soma e recebendo em pagamento letras sobre o Governo de Montevidéu na razão de três por um e os prazos que convencionar." (Correspondência de Andrés Lamas a Manuel Herrera y Obes, Rio de Janeiro, 21 de março de 1850. In: Correspondencia... 1915. Cópias, n. 3). Nessa comunicação, a publicação aparece sem o nome do autor.

21 Correspondência de Andrés Lamas a Manuel Herrera y Obes, Rio de Janeiro, 21 de março de 1850 (Correspondencia..., 1915, Cópias, n. 3).

22 Correspondência de Andrés Lamas a Manuel Herrera y Obes, Rio de Janeiro, 21 de março de 1850 (Correspondencia..., 1915. Cópias, n. 4).
} 
imperial de ter feito várias dessas remessas de armamentos sem autorização legislativa. ${ }^{23}$

Devido a esses mecanismos criados para ocultar a operação do governo brasileiro, diversas questões ficam em aberto e merecem ser analisadas mais profundamente. Em nenhuma das fontes utilizadas neste trabalho, por exemplo, aparece o nome do negociante citado. Lídia Besouchet afirmou que se tratava de Irineu Evangelista de Souza, mas não apresentou a fonte que nos permita confirmar essa ideia. A informação que pode ter dado essa pista à autora foi que parte do material a ser enviado para Montevidéu seria fundido na Ponta de Areia ${ }^{24}$ empresa de Irineu. ${ }^{25}$ Seguindo a afirmação de Besouchet, mas também sem apontar a fonte da informação, o autor Jorge Caldeira (2004), em sua biografia de Mauá, referiu-se à citação do parágrafo anterior como sendo reflexo da falta de otimismo de Irineu de receber o pagamento referente a essas mercadorias que forneceria. Mas essa nos parece ser uma análise equivocada da frase, por três principais razões.

Primeiramente, porque Lamas explicitou que essa negociação era uma simulação para disfarçar um socorro proveniente do Brasil. ${ }^{26}$. Em segundo lugar, porque ficou acertado com Paulino na reunião do dia 20 de fevereiro que a Defensa não teria que fazer nenhum desembolso referente ao recebimento dessas mercadorias. ${ }^{27}$ Por último, porque provavelmente Irineu foi chamado por Paulino para ser intermediário na transação. Observando a forma com que se encaminharam as ações do Império do Brasil naquela conjuntura, é bastante provável que Irineu tenha sido utilizado como um mediador para uma transação entre os governos. São vários os fatores que podem ter levado o gabinete conservador do Império a escolher Irineu para fazer o papel de intermediador. Ele possuía relações sociais com membros do gabinete

\footnotetext{
${ }^{23}$ Discurso do Deputado Melo Franco, sessão de 3 de junho de 1851 (Brasil, 1878, p. 336).

${ }^{24}$ Correspondência de Andrés Lamas a Manuel Herrera y Obes, Rio de Janeiro, 21 de março de 1850 (Correspondencia..., 1915). Sobre a fundição Ponta de Areia e as relações da empresa com o Império, ver Momesso (2007).

${ }^{25} \mathrm{O}$ primeiro documento desse contexto em que aparece o nome de Irineu é de 7 agosto de 1850, quando ele escreveu a Lamas oferecendo um auxílio financeiro ao Governo Oriental (Defensa). Essa carta está publicada no livro de Besouchet (1977, p. 39).

26 “Deseando que de esta simulación quedase algo escrito aunque fuera entre el señor Castro y yo, le dirigí el 28 de febrero una carta manifestando no comprender lo que se quería y declarando que no firmaría un contrato usurero que desnaturalizaba el socorro que se nos ofrecía y le quitaba todas las benéficas ulterioridades que podía producir para las relaciones de todos los países." (Correspondência de Andrés Lamas a Manuel Herrera y Obes, Rio de Janeiro, 21 de março de 1850. In: Correspondencia..., 1915, grifo nosso).

27 “[...] tengo la satisfacción de decir a Vd. que enviaré la pólvora y las municiones que se necesitan en los primeros buques. No tendrán Vds. que hacer el mínimo desembolso." (Correspondência de Andrés Lamas a Manuel Herrera y Obes, Montevidéu, 22 de fevereiro de 1850. In: Correspondencia..., 1913).
} 
conservador, ${ }^{28}$ também devido aos círculos da maçonaria em que participava. Nesse contexto, já vinha desempenhando alguns papéis importantes em políticas governamentais, como na participação da formulação do Código Comercial, por exemplo, assim como já havia recebido financiamento público para sua empresa Ponta de Areia. ${ }^{29}$

Como fundição e estaleiro, a Ponta de Areia foi estratégica também na produção de alguns armamentos e embarcações para a guerra que se aproximava. ${ }^{30}$ Mas do ponto de vista financeiro é que Irineu possuía uma grande vantagem, não apenas pela riqueza que já havia acumulado, mas também pelo seu papel de negociante na Praça do Rio de Janeiro primeiro como diretor da firma britânica Carruthers \& Co. ${ }^{31}$ depois por sua sociedade na empresa chamada Carruthers, De Castro \& Co., criada em 1840, sediada em Manchester. Segundo Anyda Marchant (1965, p. 117), essa empresa foi o meio pelo qual o capital era levantado na Inglaterra e fluía para os empreendimentos de Irineu no Brasil e no exterior. Essa característica, especificamente, é que tornava Irineu ainda mais oportuno, ${ }^{32}$ já que depois de encontrada a forma de fornecer os materiais bélicos para a Defensa e enviados os primeiros volumes de mercadorias, Lamas tentaria insistentemente conseguir recursos pecuniários no Brasil.

A França iniciou de fato a sua retirada da Guerra Grande reduzindo os subsídios a Montevidéu. Em junho de 1850, José Ellauri, enviado do governo de Montevidéu em Paris, escrevia ao Ministro Herrera y Obes que o governo francês acabava de reduzir o subsídio de 200 mil francos a 140 mil francos. ${ }^{33}$ Segundo a análise de Barrera (2015), principalmente devido à situação finan-

\footnotetext{
${ }^{28}$ Mauá trata em sua "Exposição aos credores" de 1878 sobre como vinha acompanhando as questões do Prata por sua proximidade com os ministros (Mauá, 2011, p. 123).

${ }^{29}$ Há na historiografia análises que consideram que o empréstimo realizado para a empresa Ponta de Areia em 1848 tenha sido usado como argumento para pressionar Irineu a participar do acordo, no sentido de uma troca de favores. Ver Caldeira (2004, p. 205) e Sambuccetti (1999, p. 35).

30 “Las armas, los suministros se embarcáron y llegáron en tiempo a Montevideo, [...]. Pero el gobierno de Montevideo, con cuya discreción no se contaba, no supo, hasta después de convenida la alianza, que se trataba de un subsidio oficial del Brasil; creyó en el proveedor y prestamista particular Señor Irineo de Souza; mi padre se obligó con el Emperador á esta reserva, reserva que se consideraba indispensable para retardar el rompimiento con Rozas [...].” (Lamas, 1908, p. 81). Sobre a dificuldade de manter o segredo acerca desse fornecimento de materiais, ver a correspondencia de Manuel Herrera y Obes para Andrés Lamas, Montevidéu, 23 de abril de 1850 (Correspondencia..., 1913).

${ }^{31}$ A respeito da atuação da Carruthers \& Co., ver Guimarães (2007).

${ }^{32}$ Sobre como a inserção de Irineu Evangelista de Souza nas políticas e estratégias imperiais, enquanto negociante da praça do Rio de Janeiro, fazia parte das estratégias de legitimação do Estado Imperial que estava em vias de consolidação, ver Guimarães (2012, p. 87 e 88).

${ }^{33}$ Correspondência de José Ellauri a Manuel Herrera Y Obes, Paris, 20 de junho de 1850 (Correspondencia..., 1915).
} 
ceira da França, dos 40 mil pesos estipulados pela Convenção, Montevidéu recebeu apenas 36 mil em julho de 1850, 32 mil pesos em agosto, reduzindo-se a 28 mil de outubro a junho de 1851, quando os subsídios deixaram de ser pagos e a França retirou-se definitivamente do conflito. A partir de então, além de armas o governo sitiado necessitava cada vez mais urgentemente de recursos financeiros, colocando o governo da Defensa sob uma situação crítica.

A discussão no governo montevideano era que não prolongariam a guerra se não houvesse esperança de sucesso. Uma ideia que surgiu para a resolução desse problema, segundo um novo memorando de Lamas, ${ }^{34}$ seria contratar um corpo de tropas que fortalecesse a defesa da cidade. Apenas a ideia do contrato já mudaria a "situação moral" de Montevidéu, pois traria a crença à população de que a cidade ainda poderia vencer o conflito. Mas para convencer os especuladores e conseguir levantar o capital necessário para efetivar esse plano era necessário que alguém fornecesse subsídios em substituição ao papel que a França deixaria de cumprir em breve. ${ }^{35}$

Nesse sentido, o que Lamas pedia ao ministro Paulino não era um empréstimo para contratar essa tropa, mas "uma pequena parte" do que necessitavam para que produzisse nos especuladores "a mesma impressão que espera produza na população". ${ }^{36}$ Assim conseguiriam não apenas o contrato de transporte da tropa como também materiais de guerra e equipamentos. Para tanto, o governo da Defensa contava que com uma soma de 18 a 20 mil pesos fortes mensais por 13 a 14 meses já seria possível alcançar esses objetivos e suprir a redução do subsídio francês. ${ }^{37}$ Lamas convenceu o ministro Paulino, de forma que a ajuda brasileira viria novamente de forma bastante parecida ao que foi proposto pelo plenipotenciário uruguaio.

\section{Os subsídios financeiros: Irineu entre dois papéis}

O Império do Brasil assumiria o pagamento de subsídios à Defensa com meios parecidos aos dos franceses, só que secretamente. Esse segredo era importante para que a França não cancelasse completamente o pagamento dos sub-

\footnotetext{
${ }^{34}$ Andrés Lamas, Memorandum, Rio de Janeiro, 11 de julho de 1850 (Brasil, 1852, anexo D, N. 2).

35 “Essa situação é mortal: e só pode remediar-se, na falta de um apoio ostensivo que substitua o da França, por alguma operação que alimente o espírito e a esperança pública com a apparição de recursos inesperados. Estes recursos, por isso mesmo que são inesperados, terão inmensa importancia, sem revelar precisamente a acquisição de um novo apoio externo, o farão presumir" (Andrés Lamas, Memorandum, Rio de Janeiro, 11 de julho de 1850. In: Brasil, 1852, anexo D, N. 2).

${ }^{36}$ Andrés Lamas, Memorandum, Rio de Janeiro, 11 de julho de 1850 (Brasil, 1852, anexo D, N. 2).

${ }^{37}$ Andrés Lamas, Memorandum, Rio de Janeiro, 11 de julho de 1850 (Brasil, 1852, anexo D, N. 2).
} 
sídios que vinha oferecendo desde 1848 e que já vinha passando por reduções. Dessa vez, os documentos comprovam que Irineu declarava publicamente ser o prestamista do governo da Defensa. A resolução formal da questão ocorreu em 6 de setembro de 1850, quando foram firmados dois contratos: um que permaneceu secreto, do qual era signatário o Império do Brasil, o governo uruguaio e Irineu; já no segundo, que seria público, constavam apenas Irineu e o governo uruguaio. Apesar de esse último ocultar o verdadeiro credor e os reais termos, não seria necessariamente um falso contrato.

Um tópico era comum aos dois documentos: seria fornecido o mínimo que Lamas disse ser suficiente: 18 mil pesos fortes mensais (dez mil pesos a mais do que a primeira redução francesa), por 13 meses, a partir de julho daquele ano, somando 234 mil pesos fortes. Como o contrato foi feito em setembro, as parcelas de julho a setembro seriam pagas em outubro e as demais parcelas ao final de cada mês correspondente. Outra semelhança era a cláusula que determinava que qualquer outro empréstimo que o governo uruguaio recebesse seria utilizado para pagar os subsídios acordados. Entretanto, havia diferenças significativas entre os dois contratos que visavam ocultar completamente a participação do governo brasileiro.

No que diz respeito à forma em que se dariam esses subsídios, Irineu Evangelista atuaria como intermediário, recebendo as letras do governo brasileiro e repassando as quantias para o governo uruguaio, o que publicamente seria entendido apenas como um pagamento do negociante à Defensa. Mas o Art. $6^{\circ}$ do contrato secreto estipulava que ele deveria receber os documentos do governo oriental para comprovar a entrega dos subsídios e que seu compromisso com o governo brasileiro estaria extinto com o repasse desses papéis ao mesmo, o que expressa a verdadeira origem do capital emprestado. Esses documentos serviriam como títulos da dívida do governo uruguaio para com o Brasil. No contrato público a entrega desses documentos a Irineu também era determinada, ainda que sem mencionar o Império.

Quanto aos juros, eram duplamente mais onerosos no contrato público do que no secreto, mas eram os juros de $6 \%$ ao ano que valeriam na realidade. Por fim, os dois contratos eram distintos também em suas determinações em caso de queda da praça de Montevidéu: no contrato com o Brasil, estipulava-se a entrega de soldados, armamentos e equipamentos que houvessem sido comprados com aqueles fundos, enquanto no contrato apenas com Irineu determinava-se a redução das mensalidades para 12 mil pesos e a entrega dos objetos comprados, tal como se detalha no Quadro 1. 


\section{Quadro 1 - Principais diferenças entre os contratos de 6 de setembro de 1850}

\begin{tabular}{|c|c|c|}
\hline & Secreto & Público \\
\hline Signatários & $\begin{array}{l}\text { - Império do Brasil (Paulino José Soares } \\
\text { de Souza) } \\
\text { - República Oriental do Uruguai } \\
\text { (Andrés Lamas) } \\
\text { - Irineu Evangelista de Souza }\end{array}$ & $\begin{array}{l}\text { - República Oriental do Uruguai } \\
\text { (Andrés Lamas) } \\
\text { - Irineu Evangelista de Souza }\end{array}$ \\
\hline Forma & $\begin{array}{l}\text { "Essas prestações serão entregues ao } \\
\text { governo oriental por intermedio de } \\
\text { Irenêo Evangelista de Souza, que as } \\
\text { haverá do thesouro em letras sacadas à } \\
\text { ordem, e endossadas em branco, sobre a } \\
\text { agencia de Londres, para serem pagas nas } \\
\text { épocas acima declaradas." }\end{array}$ & $\begin{array}{l}\text { "O Sr. Irinêo Evangelista de Souza se } \\
\text { obriga a entregar ao ministro oriental } \\
\text { nessa corte por conta de seu governo, } \\
\text { a quantia mensal de dezoito mil } \\
\text { pesos fortes [...]." }\end{array}$ \\
\hline $\begin{array}{l}\text { O } \\
\text { compromisso } \\
\text { de Irineu } \\
\text { com o } \\
\text { governo } \\
\text { brasileiro }\end{array}$ & $\begin{array}{l}\text { "Os documentos que o dito Irineu } \\
\text { Evangelista de Souza houver do governo } \\
\text { oriental da entrega daquellas quantias } \\
\text { servirão de descarga ao mesmo Irenêo } \\
\text { Evangelista de Souza para com o } \\
\text { governo do Brasil [...]. A } \\
\text { responsabilidade do dito Irenêo para } \\
\text { com o thesouro ficará extincta com a } \\
\text { entrega de taes documentos." }\end{array}$ & Nada consta. \\
\hline $\begin{array}{l}\text { Títulos de } \\
\text { dívida }\end{array}$ & $\begin{array}{l}\text { Os documentos que Irineu recebesse do } \\
\text { governo oriental "ficarão servindo de } \\
\text { título da dívida do governo oriental para } \\
\text { com o Brasil". }\end{array}$ & $\begin{array}{l}\text { "O ministro da Republica Oriental } \\
\text { do Uruguay dará documento ao Sr. } \\
\text { Evangelista de Souza das quantias } \\
\text { que receber em virtude deste } \\
\text { contrato." }\end{array}$ \\
\hline Juros & $\begin{array}{l}\text { "Expirados os treze meses, pagará o } \\
\text { governo oriental ao do Brasil o juro de } \\
\text { seis por cento ao anno pela totalidade } \\
\text { das prestações entregues." }\end{array}$ & $\begin{array}{l}\text { "[...] estas quantias vencerão o juro } \\
\text { de um por cento ao mez até sua } \\
\text { devolução pelo governo oriental." }\end{array}$ \\
\hline $\begin{array}{l}\text { No caso da } \\
\text { queda da } \\
\text { praça de } \\
\text { Montevidéu... }\end{array}$ & $\begin{array}{l}\text { "[...] serão postos à disposição do } \\
\text { governo do Brasil, se assim lhe convier, } \\
\text { os individuos que o governo oriental } \\
\text { engajar, convindo elles nisso, e bem assim } \\
\text { todo armamento, equipamento e outros } \\
\text { objectos havidos con aquelles fundos." }\end{array}$ & $\begin{array}{l}\text { "[...] a mensalidade ficará reduzida a } \\
\text { doze mil pesos fortes desde aquelle } \\
\text { successo." } \\
\text { "os objectos havidos com o fundo da } \\
\text { mensalidade de doze mil pesos } \\
\text { ficarão á disposição do fornecedor do } \\
\text { emprestimo, que disporá dos mesmos, } \\
\text { transferindo ou alienando seu direito } \\
\text { como melhor convenha." }\end{array}$ \\
\hline
\end{tabular}

Fonte: elaboração própria com base nos contratos disponíveis em Brasil (1852, anexo G, N. 1 e 2). ${ }^{38}$

38 Outra diferença estava na referência ao cancelamento de um contrato de 21 de agosto de 1850 que só aparece no contrato 
Para que o nome do Império não aparecesse, as letras do Tesouro brasileiro estariam sem identificação do beneficiário, de modo que poderiam ser utilizadas como meio de pagamento para outras transações. É provável que isso queira dizer que não necessariamente essas letras chegariam às mãos do governo uruguaio, porque essas letras sairiam da "agência de Londres". Como "agência de Londres" o governo se referia à casa Goldsmid, King e Thompson, que estava encarregada das transações financeiras do Tesouro brasileiro naquela cidade, sobretudo no tocante ao pagamento das dívidas externas brasileiras. ${ }^{39}$ Nesse sentido, é possível que Irineu utilizasse a empresa Carruthers, De Castro \& Co. em Manchester para fazer a troca das letras do tesouro por algum documento de crédito próprio, de forma a poder entregar para Andrés Lamas meios de pagamentos que apagassem o rastro do governo brasileiro nessa transação. Nessa hipótese, não haveria risco, porque Irineu teria ficado com as letras do tesouro para si, e como grande empresário, poderia utilizar para posterior pagamento de impostos, por exemplo.

Todo esse mecanismo de negociações e documentos secretos confundiu historiadores. Várias histórias foram contadas acerca desse envolvimento de Irineu na geopolítica platina, em geral analisando como se o capital empregado nessas transações fosse seu. ${ }^{40}$ Entretanto, como fica claro na exposição feita até aqui, a entrada do negociante nos meandros da geopolítica platina foi como intermediário. O próprio Irineu (já com o título de barão) afirmou em sua "Exposição aos credores" que já vinha acompanhando os acontecimentos na região platina desde o início de 1850 e em "meados desse ano" o ministro Paulino lhe disse que seria necessário sustentar a praça de Montevidéu com recursos financeiros. Mauá afirmou: “[...] o governo confiava em mim para prestar os auxílios indispensáveis como suprimentos por mim feitos" (Mauá, 2011, p. 124, grifo nosso), ou seja, como se fossem feitos por Irineu.

Parece, portanto, que estava claro desde o início o que o Império esperava de Irineu. Na análise de Caldeira, Irineu emprega seu dinheiro em uma aventura sem muitas esperanças de recebê-lo de volta como se tivesse agido

público. Aquele contrato foi negociado entre o Governo da Defensa e Irineu, mas foi suspenso alguns dias depois (MHN, R/3/086, T. IV, folha 73).

39 Casas de comércio começaram a cumprir essa função após a extinção da Caixa da legação de Londres pela Lei de 4 de dezembro de 1830. A casa Goldsmith, King e Thompson assumiu o compromisso a partir de um contrato com o governo brasileiro de 1840, substituindo a casa Samuel Phillips.

${ }^{40}$ Jorge Caldeira, em uma das mais famosas biografias acerca de Mauá, afirma que o Ministro Paulino pediu para Irineu uma resposta rápida a sua proposta que seria: "Irineu deveria financiar o governo uruguaio com dinheiro do seu bolso, o qual seria ressarcido depois, quando tudo tivesse mudado ao sul do Brasil" (Caldeira, 2004, p. 205, grifo nosso). Essa linha de análise é reproduzida por Sambuccetti (1999, p. 35). 
por "um toque de convocação". ${ }^{41}$ Entretanto, aprofundando a análise nas fontes e na historiografia, podemos perceber que a margem de manobra do negociante não era assim tão estreita e que sua atuação para além do papel de intermediário proposto pelo governo parece ter sido mais uma oportunidade do que uma imposição. ${ }^{42} \mathrm{Com}$ a negociação, foi possível fazer outras apostas enquanto um grande negociante inspirado nos exemplos ingleses.

Como apresentamos anteriormente, o Império estava emprestando o que Lamas havia proposto com o objetivo de atrair especuladores que apostassem na vitória da Defensa, oferecendo mais crédito para aquele governo. Irineu tornou-se um desses especuladores. Em nota apresentada ao governo brasileiro, em 3 de abril de 1851 (Brasil, 1852, anexo D, N. 3), Lamas afirmou que além dos contratos realizados em 6 de setembro do ano anterior, houve também um contrato com particulares assinado no dia seguinte. $O$ novo contrato tinha participação de vários comerciantes, embora figurasse apenas o nome de Irineu. $\mathrm{O}$ contrato particular de 7 de setembro foi assinado entre Andrés Lamas e General Melchor Pacheco y Obes, como representantes do governo oriental, e Irineu Evangelista de Souza, a frente de vários indivíduos do comércio. Esse novo contrato abria um crédito ao General Melchor de 1.220.000 francos em nome do Governo Oriental, para transporte, armamento e equipagem de um exército de 3 mil homens ou menos. ${ }^{43}$

O documento de 7 de setembro possuía uma intrincada relação com os subsídios brasileiros: estipulava-se que das três primeiras mensalidades que seriam entregues pelo governo brasileiro, no valor de 54 mil pesos fortes, 42 mil seriam retidos por Irineu; e das dez mensalidades de 18 mil pesos fortes, 13.200 pesos/mês ficariam com o negociante brasileiro. Essa soma era de 174 mil pesos fortes, ou seja, quase $75 \%$ do empréstimo brasileiro ao governo oriental ficaria em posse de Irineu para que ele fornecesse o empréstimo em francos. ${ }^{44} \mathrm{O}$ barão de Mauá escreveu sobre essa sua empreitada particular, explicando que ao perceber que os recursos ofertados pelo Império eram insufi-

\footnotetext{
${ }^{41}$ Ganns (2011, p. 72), Caldeira (2004, p. 205), Sambucetti (1999, p. 35).

${ }^{42}$ Para Alberto de Faria, que em sua análise exaltava a característica de empreendedor de Irineu, considerava que a inserção do negociador nesses negócios com capital próprio teria a ver com sua personalidade: "Não estava, porém, no temperamento de Mauá o papel de simples intermediário, de agente", e por isso teria "se lançado de corpo e alma" nos negócios platinos (Faria, 1933, p. 280).

${ }^{43} \mathrm{O}$ general Melchor havia passado pelo Rio de Janeiro quando estava a caminho da Europa enquanto Enviado Extraordinário e Ministro Plenipotenciário em missão especial junto ao Governo da França. Nesse contexto negociou junto a Lamas e Irineu o contrato que também assinou. Desse contrato, 6 mil pesos fortes foram entregues ao general para os gastos de sua missão (MHN, R/3/086, T. IV, folha 90).

${ }^{44} \mathrm{MHN}, \mathrm{R} / 3 / 086, \mathrm{~T}$. IV, folha 90.
} 
cientes, e tendo ele "sobra de recursos", resolveu auxiliar a defesa da praça com "recursos que bastassem” com “módico juro relativo” (Mauá, 2011, p. 125), contrastando com a análise de Lamas que dizia que os juros podiam "parecer grandes e até exorbitantes". ${ }^{45}$ De todo modo, é certo que pela instabilidade em que se encontrava o governo de Montevidéu, qualquer empréstimo era bastante arriscando aos prestamistas, o que elevava os juros de mercado.

Nesse sentido, deve ser a esse contrato particular do dia 7 a que se refere o Artigo $4^{\circ}$ do contrato secreto de 6 de setembro, que estipulava que caso caísse a praça de Montevidéu, os subsídios de 18 mil pesos seriam reduzidos a 12 mil pesos, que continuariam sendo entregues a Irineu "para amortização dos adiantamentos por elle feitos ao governo oriental". Essa é uma hipótese baseada na falta de documento que comprove qualquer pagamento feito por Irineu ao governo de Montevidéu com recursos próprios antes de 7 de setembro de 1850. Outra hipótese, que foi apresentada na historiografia, seria a de que esses adiantamentos se referem aos próprios subsídios, que teriam sido pagos por Irineu para o governo de Montevidéu, para depois serem ressarcidos pelo Império.

Segundo Barrera (2015, p. 306), Irineu era quem realmente adiantava o dinheiro para a praça de Montevidéu e seu ressarcimento só ocorreu a partir do Decreto $n^{\circ} 861$ de 14 de novembro de 1851. Esse decreto abria um crédito extraordinário ao Ministério dos Negócios Estrangeiros de 266 mil pesos fortes para quitar os valores referentes aos contratos de 6 de setembro de 1850 e os contratos de $1^{\circ}$ de dezembro. ${ }^{46}$ Este último contrato estipulava

\footnotetext{
45 “Neste contracto o meu governo apresentava só como effectivo a parte em dinheiro que destinou para este objecto das treze mensalidades; e como ella era muito inferior á somma que o /sr. Irenêo e seus co-associados ião desembolsar, estipularão-se interesses que podem parecer grandes e até exorbitantes, maxime neste paiz e em circunstancias normaes, porém que erão, quando menos, iguaes aos que podião obter-se pela applicação desses fundos a outras transacções mais seguras em Montevidéo, e infinitamente inferiores ao grande risco a que expunhão o capital desembolsado" (Andrés Lamas, Nota da Legação da Republica Oriental do Uruguay ao Governo Imperial, Rio de Janeiro, 3 de abril de 1852. In: Brasil, 1852, anexo D, N. 3).

${ }^{46} \mathrm{Em} 1^{\circ}$ de dezembro de 1850 , foram realizados dois contratos, mantendo novamente um deles em segredo. $\mathrm{O}$ contrato público era entre Andrés Lamas (representando o governo uruguaio) e Irineu Evangelista de Souza. Acordava-se que Irineu, "em seu nome e por sua conta", entregaria a Lamas 4 mil pesos fortes mensais, por oito meses contados a partir de novembro. Essas entregas só poderiam ser interrompidas se a França voltasse a assumir esses pagamentos, ou se a praça de Montevidéu caísse sob o poder de Oribe. Os juros seriam de $1 \%$ ao mês até serem reembolsados pelo governo oriental. Já o contrato secreto era entre Paulino José Soares de Souza (representando o governo brasileiro) e Irineu, aprovando o contrato anterior. Neste contrato secreto esclarecia-se que os 4 mil pesos fortes mensais seriam entregues pelo governo imperial a Irineu, que serviria como "mero intermediário" ao repassá-los a Lamas. Assim como no contrato de setembro, Irineu deveria reunir os recibos dessas entregas e entregá-los ao governo imperial, de modo a encerrar sua responsabilidade nessa transação. E os recibos serviriam como títulos da dívida uruguaia para com o Brasil. Os juros seriam de 6\% ao ano. Os pagamentos foram realizados, portanto, de dezembro de 1850 a junho de 1851.
} 
um novo subsídio de 4 mil pesos para suprir a nova redução dos pagamentos franceses (Brasil, 1852, anexo G, N. 5). Entretanto, não parece ter sido essa a prática realizada nos pagamentos dos referidos subsídios à Defensa. É bastante provável que algum valor tenha sido adiantado por Irineu Evangelista, porque a pressa maior do acordo era embarcar o General Melchor para a Europa, e o Brasil só pagaria a partir de outubro. ${ }^{47}$ Mas isso não teria ocorrido com todas as mensalidades.

Em ordem expedida no mesmo dia do referido Decreto, o ministro Paulino informou estar remetendo diversos documentos para o ministro da Fazenda, Joaquim José Rodrigues Torres. ${ }^{48}$ Eram os documentos que Irineu havia ficado incumbido de receber do governo oriental comprovando a entrega dos subsídios e que ficariam como títulos da dívida uruguaia para com o Brasil. A entrega desses títulos ao governo brasileiro extinguiria a responsabilidade de Irineu com o contrato. Mas, contrariamente ao que afirmou Barrera (2015), ${ }^{49}$ o ministro Paulino afirmou nessa nota que os créditos seriam destinados ao Ministério da Guerra, que seria de onde teriam saído os recursos para o pagamento dos subsídios. ${ }^{50}$ Irineu, em um discurso na Câmara dos Deputados em 1873, informou que seu papel na entrega dos subsídios foi apenas de intermediário e que recebeu as quantias a serem entregues pela secretaria da polícia ou pelo tesouro nacional. ${ }^{51}$

Ao final do contrato secreto publicado no Relatório da Repartição dos Negócios Estrangeiros, há uma nota datada de 3 de outubro de 1850 informando que Irineu recebeu as letras a serem utilizadas para o pagamento das mensalidades em "saques ao thesoureiro geral do thesouro publico sobre a agencia de Londres à sua ordem" (Brasil, 1852, anexo G, N. 1). Ao que tudo indica, portanto, o Império não ficou devendo nada para Irineu e esses subsídios da Diplomacia do Patacão foram inteiramente despendidos pelo Império do Brasil desde o começo, ao menos no que diz respeito a esses contratos do dia

\footnotetext{
${ }^{47}$ Assim, pelo menos a quantia de 6 mil pesos fortes deve ter sido feita nesse esquema, já que o general embarcou com o dinheiro já no dia 10 de setembro.

48 Joaquim José Rodrigues Torres, mais tarde visconde com grandeza de Itaboraí, era outro líder da Trindade Saquarema do Partido Conservador (Mattos, 1987).

${ }^{49}$ Esse crédito, segundo o autor, serviria para abonar Irineu. Nesse sentido, Barrera (2015, p. 306) adverte: "não foi a última vez que um crédito de Evangelista de Souza se converteu em dívida imperial".

50 “E como as quantias que constão delles forão lançadas em despeza ao ministerio da guerra, tenho de rogar a V. Ex. que mande fazer no thesouro o extorno daquellas quantias no dito ministerio, e nas rubricas indicadas pelo respectivo ministro, lançando-as no dos estrangeiros por conta do crédito aberto pelo decreto desta data [...]." (Brasil, 1852, anexo G, N. 6).

${ }^{51}$ Discurso do deputado barão de Mauá, sessão de 4 de fevereiro de 1873 (Brasil, 1873, tomo III, p. 24).
} 
6 de setembro e $1^{\circ}$ de dezembro de 1850 . Bastava que o Império entregasse letras do Thesouro a Irineu, que poderia negociá-las da forma que melhor conviesse, repassando outro tipo de crédito ao governo uruguaio, como o fez com o contrato de 7 de setembro nominado em francos.

Criando laços creditícios estatais escondidos atrás de um negociante privado, o Império do Brasil conseguiu, com a Diplomacia do Patacão, adiar uma declaração de guerra ao mesmo tempo em que foi amarrando firmemente seus aliados à estratégia que vinha sendo criada. Iniciando pelo governo uruguaio, e se estendendo posteriormente ao General Urquiza na Confederação Argentina, os empréstimos e subsídios brasileiros contribuíram para a reunificação uruguaia (8 de outubro de 1851) e a posterior queda de Rosas na Argentina (3 de fevereiro de 1852), encerrando a chamada Guerra Grande. Após a pacificação do Uruguai, o Brasil garantiu seus interesses no país assinando cinco tratados (Tratados de 12 de outubro de 1851) que colocaram a Banda Oriental em posição de subserviência. Tendo a guerra arrasado a economia uruguaia, o que começou como um subsídio temporário por parte do Brasil foi se unindo à crescente dívida pública da Banda Oriental, aumentando sua necessidade de crédito e a dependência pelo capital brasileiro. ${ }^{52}$

\section{Considerações finais}

A Diplomacia do Patacão foi apenas um dos fatores que fizeram parte da "política brasileira de potência periférica" na região da Bacia do Rio da Prata na década de $1850,{ }^{53}$ mas pode ser um fator preponderante do ponto de vista da história econômica. Ela representou uma espécie de casamento entre poder político e capital privado. Esse casamento, que por um lado é muito comum na história dos Estados Nacionais do sistema interestatal capitalista, por outro teve características muito específicas por ocorrer na periferia desse sistema. Essa política foi um jogo de poder que se combinava, se subordinava e ao mesmo tempo desafiava o polo central de poder. O Império do Brasil era ao mesmo tempo devedor internacional e credor regional; destacava-se de seus vizinhos pela origem portuguesa, pela forma monárquica de governo, pela manutenção da escravidão. Nesse sentido, "se apresentar como

\footnotetext{
${ }^{52}$ Segundo Bandeira (2012, p. 147 e 148), o Uruguai terminou a guerra "reduzido a mero protetorado do Brasil”, dependendo "quase que exclusivamente" dos subsídios concedidos pelo Império.

53 “O período que vai de 1844 a 1876 caracterizou-se pela ascensão, apogeu e declínio de uma política brasileira de potência periférica regional, autoformulada, contínua e racional, na medida em que se guiava por objetivos próprios, aos quais subordinavam-se os métodos e os meios" (Cervo, Bueno, 2002, p. 109).
} 
concorrente" nesse sistema era "condição necessária para buscar sua sobrevivência" (Salles, 1990, p. 49). Esse casamento periférico durou enquanto duraram seus efeitos: o poderio do grande financista brasileiro no Prata teve um processo de morte junto ao do poderio regional brasileiro na década de 1870 .

A análise sobre o papel de Irineu Evangelista de Souza na Diplomacia do Patacão esbarra na dificuldade de encontrar fontes que comprovem todas as hipóteses levantadas sobre essas operações secretas. A necessidade de discrição por parte dos participantes deve ser uma das razões para que não se tenha deixado documentado os meandros das negociações. Entretanto, a partir do cruzamento das fontes existentes e das análises bibliográficas de trabalhos realizados por outros pesquisadores, podemos observar ao menos três momentos da ação do negociante na estratégia financeira brasileira para a geopolítica platina em 1850: primeiro como intermediário no fornecimento de armas por parte do Império em março; depois como intermediário no contrato financeiro de setembro, ação repetida em dezembro; e, por último, como financista que aplica seu capital privado na empreitada de apoiar o governo que era a aposta do Governo Imperial na guerra platina.

$\mathrm{Na}$ negociação de março, mesmo que Irineu tenha produzido parte das mercadorias armamentistas em sua fundição, é muito mais provável que o tenha feito como trocas de favores ou mesmo mediante pagamento do Governo Imperial do que por gasto próprio. A acusação na Câmara dos Deputados de que o Brasil enviava armamentos para o conflito do país vizinho aponta para a probabilidade de que essa pode ser apenas uma das intervenções oficiais brasileiras no conflito antes da declaração da guerra e antes dos contratos financeiros da Diplomacia do Patacão. Quando, no segundo momento, Irineu foi chamado como intermediário dos subsídios, a necessidade de manter a estratégia brasileira sob sigilo é o que determina a aparição do nome do negociante nos contratos. Caso contrário, os empréstimos poderiam ocorrer como com os franceses, que inclusive aproveitaram a dependência desses recursos pela Defensa para pressionar o governo a favor dos interesses dos súditos desse país europeu na região. O sigilo da operação era importante tanto para que a guerra contra Rosas não fosse declarada antes do tempo, como para que os franceses não retirassem seus subsídios e tornasse mais urgente a intervenção brasileira.

Por último, o terceiro momento é o de Irineu como financista, como representante de um grupo de comerciantes que forneceria o crédito necessário à Defensa para contratar mercenários e comprar armamentos europeus. 
Sua participação nos contratos secretos the permite utilizar a maior parte dos recursos brasileiros destinados a Montevidéu para fazer sua negociação privada com a Defensa. Além disso, inseriu o negociante no círculo dos negócios governamentais na região platina, abrindo-lhe diversas oportunidades de negócios que culminará na rede de agências bancárias que criou entre o Rio Grande do Sul, Uruguai e Argentina a partir da segunda metade da década de 1850. Por possuir uma fundição e uma agência financeira em Londres, Irineu pareceu o negociante ideal para os negócios secretos brasileiros. E pelo que o negociante pôde realizar posteriormente, percebe-se que seu papel ao invés de uma imposição, parece ter sido uma grande oportunidade.

\section{Fontes}

BRASIL. Annaes do Parlamento Brazileiro: Camara dos Srs. Deputados, Sessão de 1851. Rio de Janeiro: Typographia de H. J. Pinto, 1878. Tomo I.

BRASIL. Annaes do Parlamento Brazileiro: Camara dos Srs. Deputados, Sessão de 1872. Rio de Janeiro:Typographia Imperial e Constitucional de J.Villeneuve \& C., 1873. Tomo III.

BRASIL. Relatório do ano de 1850 da Repartição dos Negócios Estrangeiros apresentado à Assembleia Geral Legislativa: pelo Ministro José Paulino Soares de Souza. Rio de Janeiro:Typographia Universal de Laemmert, 1851. Disponível em: < http://ddsnext.crl.edu/brazil >. Acesso em: 25 set. 2020.

BRASIL. Relatório do ano de 1851 da Repartição dos Negócios Estrangeiros apresentado à Assembleia Geral Legislativa: pelo Ministro José Paulino Soares de Souza. Rio de Janeiro:Typographia Universal de Laemmert, 1852. Disponível em: <http://ddsnext.crl.edu/brazil >. Acesso em: 25 set. 2020.

CORRESPONDENCIA del Doctor Herrera y Obes. Diplomacia de la Defensa de Montevideo. Buenos Aires: Est. Gráfico A. de Martino, 1913. Tomo II.

CORRESPONDENCIA del Doctor Herrera y Obes. Diplomacia de la Defensa de Montevideo. Buenos Aires: Est. Gráfico A. de Martino, 1915. Tomo III. 
LAMAS, A. Memória acerca da crise política e financeira de Montevidéu, tratando dos esforços do governo brasileiro para ajudar aquela cidade. Rio de Janeiro, 26 abr. 1850. 2 doc. (41 p.). Orig. Ms. Em espanhol. Localização: Biblioteca Nacional do Brasil (BNB) 63,03,006 nº 024.

MUSEO HISTORICO NACIONAL (MHN). R/3/086. Archivo Manuel Herrera y Obes. Documentos relativos a las negociaciones diplomáticas realizadas en Río de Janeiro por Andrés Lamas. T. IV. Manuscritos. Colección Pablo Blanco Acevedo.

URUGUAY. Ministerio de Relaciones Exteriores. Coleccion de Tratados, Convenciones y otros Pactos Internacionales de la Republica Oriental del Uruguai.Tomo I (1830-1860). Montevideo: El Siglo Ilustrado, 1922. Disponível em: <https://hdl.handle.net/2027/mdp.35112102960228>. Acesso em: 3 mar. 2021.

\section{Referências}

ALMEIDA, P. R. de. Formação da diplomacia econômica no Brasil: as relações econômicas internacionais no Império. São Paulo, Brasília: Editora Senac São Paulo, Funag, 2005.

BANDEIRA, L.A. M. A expansão do Brasil e a formação dos estados na Bacia do Prata: Argentina, Uruguai e Paraguai. Rio de Janeiro: Civilização Brasileira, 2012.

BARRERA, M.E. Hijos de Mercurio, esclavos de Marte: mercaderes y servidores del estado en el Río de la Plata. Rosario: Prohistoria Ediciones; Sbla - Universidad Pompeu Fabra, 2015.

BESOUCHET, L. Correspondência política de Mauá no Rio da Prata (18501885). São Paulo: Ed. Nacional, 1977. Brasiliana, v. 227.

BESOUCHET, L. Mauá e seu tempo. Rio de Janeiro: Nova Fronteira, 1978.

CADY, J. La intervencion extranjera en el Rio de la Plata 1838-1850: estudio de la politica seguida por Francia, Gran Bretaña y Norteamerica con respecto al dictador Juan Manuel de Rosas. Buenos Aires: Editorial Losada, 1943. 
CAIN, P. J.; HOPKINS, A. G. British imperialism: 1688-2000. Oxford, New York: Routledge, 2002.

CALDEIRA, J. Mauá: empresário do Império. São Paulo: Companhia das Letras, 2004.

CÁRCANO, R. J. Del sitio de Buenos Aires al campo de Cepeda: 1852-1859. Buenos Aires: Coni, 1921.

CARR, E. H. Vinte anos de crise: 1919-1939. Uma introdução ao estudo das Relações Internacionais. Brasília: Editora Universidade de Brasília; IPRI; Imprensa Oficial do Estado de São Paulo, 2001.

CERVO, A. L.; BUENO, C. História da política exterior do Brasil. Brasília: Editora Universidade de Brasília, 2002. (Coleção O Brasil e o Mundo)

DEVOTO, J. E. P.; DEVOTO, A. R. de P. La Guerra Grande (1839-1851). Montevideo: Editorial Medina, 1971. (Colección Cien Temas Básicos, n. 17)

FARIA, A. de. Mauá. São Paulo: Companhia Editora Nacional, 1933. Brasiliana, série V, v. 20.

FERRANDO,J. Reseña del Credito Publico del Uruguay. Montevideo: Imprenta Nacional, 1969. Publicación oficial del Ministerio de Hacienda.Tomo I.

FERREIRA, G. N. O Rio da Prata e a consolidação do Estado Imperial. São Paulo: Editora Hucitec, 2006. (Estudos Históricos, 62).

FLORES, M. F. da C.T. Crimes de fronteira: a criminalidade na fronteira meridional do Brasil (1845-1889). Porto Alegre:Edipucrs, 2014. Disponível em: <ebooks.pucrs.br/edipucrs/Ebooks/Pdf/978-85-397-0481-1.pdf>. Acesso em: 30 set. 2016.

FRADKIN, R. O.; GELMAN, J. D. Juan Manuel de Rosas: la construcción de un liderazgo político. Ciudad Autónoma de Buenos Aires: Edhasa, 2015.

FRANCO, S. da C. As "Califórnias" de Chico Pedro. Porto Alegre: Martins Livreiro, 2006. 
GANNS, C. Prefácio. In: MAUÁ, Irineu Evangelista de Sousa, Visconde de. Autobiografia. Brasília: Senado Federal, Conselho Editorial, p. 19-101, 2011.

GARAVAGLIA, J. C. Algunos aspectos preliminares acerca de la "transición fiscal” en América Latina, 1800-1850. Illes I Imperis, Barcelona, n. 13, p. 159$192,2010$.

GUAZZELLI, C.A. B. O horizonte da província: a República Rio-Grandense e os caudilhos do Rio da Prata. Porto Alegre: Linus Editores, 2013.

GUIMARÃES, C. G. A presença inglesa nas finanças e no comércio no Brasil Imperial: os casos da Sociedade Bancária Mauá, MacGregor \& Cia. (1854-1866) e da firma inglesa Samuel Phillips \& Cia (1808-1840). São Paulo: Alameda, 2012.

GUIMARÃES, C. G. O comércio inglês no Império brasileiro: a atuação da firma inglesa Carruthers \& Co., 1824-1854. In: CARVALHO, José Murilo de (Org.). Nação e cidadania no Império: novos horizontes. Rio de Janeiro: Civilização Brasileira, p. 371-393, 2007.

HOBSBAWM, E. A era das revoluções, 1789-1848. Rio de Janeiro, São Paulo: Paz e Terra, 2019.

LAMAS, P. S. Etapas de una gran política. Sceaux: Imprenta Charaire, 1908.

MARCHANT, A. Viscount Mauá and the Empire of Brazil: a biography of Irineu Evangelista de Souza (1813-1889). Berkeley, Los Angeles: University Of California Press, 1965.

MATTOS, I. R. de. O tempo saquarema. São Paulo: HUCITEC, 1987.

MAUÁ, Irineu Evangelista de Sousa,Visconde de. Autobiografia. Brasília: Senado Federal, Conselho Editorial, 2011.

MENEGAT, C. "Transportando fortunas para povoar deserta e inculta campanha": atuação política e negócios dos brasileiros no norte do Estado 
Oriental do Uruguai (ca. 1845-1865). Porto Alegre: UFRGS, 2015 (Tese de Doutorado em História da UFRGS).

MESSIAS, T.A. de.A Guerra Grande e a Província de São Pedro (1839-1852). Revista Instituto Histórico e Geográfico do Rio Grande do Sul, n. 154, p. 89-114, jul. 2018.

MOMESSO, B. P. Indústria e trabalho no século XIX: o Estabelecimento de Fundição e Máquinas de Ponta da Areia. Dissertação. Niterói: UFF, 2007 (Dissertação de Mestrado em História da UFF).

PETTY,W.Tratado dos impostos e contribuições. In: PETTY, William. Obras econômicas. São Paulo: Abril Cultural, p. 1-12, 1983. Coleção Os Economistas.

PUIGGRÓS, R. Historia económica del Río de la Plata. Buenos Aires: Retorica Ediciones; Altamira, 2006.

RIBEIRO, J. I. As "Sorpresas" de Chico Pedro, as astúcias de Moringue: Francisco Pedro de Abreu, o Barão de Jacuí. São Leopoldo: Oikos, 2021. E-book.

SALLES, R. Guerra do Paraguai: escravidão e cidadania na formação do exército. Rio de Janeiro: Paz e Terra, 1990.

SAMBUCCETTI, S. I. R. de. Urquiza y Mana: el Mercosul del siglo XIX. Buenos Aires: Ediciones Macchi, 1999.

SCHULZ, J. A crise financeira da abolição. São Paulo: Edusp, 2013.

SOARES, T. O gigante e o rio: ação de Mauá no Uruguai e Argentina (18511878). Rio de Janeiro: Companhia Brasileira e Artes Gráficas, 1957.

SOUZA, J. S. de. A Diplomacia do Patacão: queda de Rosas e a nova configuração de forças no Prata (1850-1858). Brasília: UnB, 2013 (Dissertação de Mestrado em Relações Internacionais da UnB).

SOUZA, J. A. S. de. A vida do visconde do Uruguai (1807-1866). São Paulo: Companhia Editora Nacional, 1944. Brasiliana, série V, v. 243. 
VARGAS, J. M. Pelas margens do Atlântico: um estudo sobre elites locais e regionais no Brasil a partir das famílias proprietárias de charqueadas em Pelotas, Rio Grande do Sul (século XIX). Rio de Janeiro: UFRJ, 2013 (Tese de Doutorado em História Social da UFRJ). 